\title{
Cinémas
}

Revue d'études cinématographiques

Journal of Film Studies

\section{Germans Suffering in Spain: Cold War Visions of the Spanish Civil War in Fünf Patronenhülsen (1960) and Solange du lebst (1955)}

\section{La souffrance des Allemands en Espagne : points de vue de la guerre froide sur la guerre civile espagnole dans Fünf Patronenhülsen (1960) et Solange du lebst (1955)}

\section{Stefan Soldovieri}

Volume 18, numéro 1, automne 2007

Mémoires de l’Allemagne divisée. Autour de la DEFA

URI : https://id.erudit.org/iderudit/017846ar

DOI : https://doi.org/10.7202/017846ar

Aller au sommaire du numéro

Éditeur(s)

Cinémas

ISSN

1181-6945 (imprimé)

1705-6500 (numérique)

Découvrir la revue

Citer cet article

Soldovieri, S. (2007). Germans Suffering in Spain: Cold War Visions of the Spanish Civil War in Fünf Patronenhülsen (1960) and Solange du lebst (1955). Cinémas, 18(1), 53-69. https://doi.org/10.7202/017846ar
Résumé de l'article

Depuis 1989, les liens entre les industries cinématographiques de ce qui avait été jusque-là deux Allemagnes géopolitiquement divisées, attirent de plus en plus l'attention. Le présent article propose d'étudier comment deux films d'après-guerre - l'un produit en Allemagne de l'Est, l'autre en Allemagne de l'Ouest - représentent de différente façon la souffrance et le sacrifice allemands. L'auteur défend l'idée que malgré leurs horizons politiques opposés, les deux films participent d'un discours de la souffrance qui transcende la dualité de l'Allemagne et qui, au-delà de ses transformations historiques, demeure constant tout au long de la guerre froide. 


\title{
Germans Suffering in Spain: Cold War Visions of the Spanish Civil War in Fünf Patronenhülsen (1960) and Solange du lebst (1955) ${ }^{1}$
}

\section{Stefan Soldovieri}

\begin{abstract}
Since 1989 connections between the once geopolitically divided German movie industries have received increasing attention. This article considers how two films of the early post-war period-one produced in East Germany and one from the West-mobilized in different ways figurations of German suffering and sacrifice. The author argues that despite their diverging politics, the two films participate in a trans-German discourse of suffering that persisted in historically variable ways throughout the Cold War period.
\end{abstract}

Voir le résumé français à la fin de l'article

Since German unification comparative approaches have begun to uncover previously neglected points of contact between the Cold War German cinemas. ${ }^{2}$ In the interest of exploring the "contrastive dialogue" ${ }^{3}$ — to borrow a formulation that has been used in studies of German television-between the Cold War German cinemas in East and West, I would like to present a comparative reading of Frank Beyer's Fünf Patronenhülsen (Five Cartridges, DEFA, 1960) and Harald Reinl's Solange du lebst (As Long as You Live, FRG, 1955). Set during the Spanish Civil War, whose memory occupied very different places in East and West Germany, the films reveal symptomatic aesthetic, narrative, and ideological divergences as well as shared preoccupations in the early post-war German cinemas. I suggest that despite their radically different politics and the very different ways in which their images could be read in their 
respective contexts, the films draw on related figurations of German suffering and sacrifice which connect them to contemporary discourses on German victimization and national belonging.

The struggle over the meaning to be attached to the suffering experienced by "ordinary Germans" during the final months of the Second World War has continued to resurface in public debates since historian Ernst Nolte's neo-conservative challenge in 1986 to the historiography of the Nazi past. But the West German Historikerstreit or historians' controversy ignited by Nolte's plea for a "normalisation" of Germany's relationship to its past was only the most recent instrumentalization of German suffering in the search for a "usable past." In the context of a unified, post-Cold War Germany the discourse of German victimization and culpability has flared up repeatedly in public debates, such as those surrounding the photo exhibition on crimes perpetrated by the Wehrmacht, the Holocaust memorial in Berlin and most recently in Günter Grass's revelations in his autobiography Beim Häuten der Zwiebel (Peeling the Onion, 2007) regarding his brief service at age 17 in the Waffen SS. As Robert G. Moeller (2001, p. 193) notes: "The past of German victimization did not have to be scripted anew, because it was already in place." A consideration of Fünf Patronenhülsen and Solange du lebst suggests that the German cinemas of the early post-war period can be productively interrogated as spaces in which contrastive discourses on German suffering were being negotiated.

War was a pervasive topos in the West German cinema of the 1950s. ${ }^{5}$ Over 200 war films were screened in West German cinemas from 1948-59, half of which hailed from the U.S. as Hollywood sought to establish dominance of the German market. With the escalation of the Cold War following the creation of NATO in 1949 and the outbreak of the Korean War in 1950, a situation arose in which the Western military alliance actively sought German participation. Supported in part by a system of government financial guarantees introduced in 1952, the West German film industry responded to military integration with a wave of war films that remained popular into the 1960s. The 
genre was economically successful and also the subject of heated public debate.

As Anton Kaes, Robert Moeller and others have noted, the war films produced in West Germany during the 1950s reveal visual and narrative continuities with the war-based propaganda films of the Nazi period even where they seem to articulate pacifist sentiments. Characterized visually by naturalistic images of combat, by spectacles of violence and destruction, films like Alfred Weidenmann's Der Stern von Afrika (1956) and Paul May's 08/15 trilogy rescued decent German soldiers and petty officers from an evil regime. At the same time they promoted values of valour, duty, chivalry among soldiers of all nations, and love of country which, in the trans-historical, generalized form in which they were presented, could be embraced even in the fraught ideological context of post-war West Germany. Robert Moeller notes that while West German military planners and politicians considered what shape the new West German military should take, May's 08/15 films suggested continuities between the soldiers of a new German army-touted by military reformers as "citizens in uniform" and defined by obligations to friends, family, and community - and the previous tradition of military service. 08/15 was a version of the past that appealed to many West Germans. As many as 15-20 million West Germans saw Part I, which earned some 4 million dollars in one month and outgrossed the most successful Heimatfilm of the 1950s, Hans Deppe's Schwarzwaldmädel (Black Forest Girl, 1950). ${ }^{6}$

Harald Reinl's Solange du lebst shares many of the visual strategies and narrative features typical of the West German war film. Set during the Spanish Civil War, which was fought from 18 July 1936 to 1 April 1939, the film nonetheless mobilized the same issues of national belonging, anti-communism, and selective remembering of historical events characteristic of West German features set during the Second World War. In fact Solange du lebst was not the only Spanish Civil War drama to recast fascism as anti-communism in movie houses in the Federal Republic. In 1957 the West German film industry imported Spanish director José María Forqués 1956 
Embajadores en el infierno (Ambassadors to an Inferno), which was devoted to the Blue Division, a force of Spanish volunteers who fought for Hitler's army on the Eastern front and suffered severe casualties. ${ }^{7}$ To be sure West German audiences would also encounter Juan Antonio Bardem's Muerte de un ciclista (Death of a Cyclist, 1955). Bardem was one of the few politically engaged directors able to work-albeit under constant threat of arrest - under the strictures of Franco's regime and Muerte de un ciclista is generally credited with being the first Spanish film to shed critical light on the Spanish Civil War. Still, the West German premiere on 9 October 1959 followed the GDR release by more than a year, and the film's subtle questioning of the aftershocks of the Spanish conflict had more to do with the repression of memory of the war than its specific politics. And whereas the GDR film industry would go on to secure a number of Bardem films and even co-produce a biopic by the director, Preduprazhdenieto (The Warning, 1982), dedicated to the revolutionary figure Georgi Dimitroff, his reception in the West remained inconsistent. Indicative of the differential treatment of the regime-critical Spanish director-and perhaps even of the cordial relations between the West German government and Franco's Spain throughout the late 1960s — of the other Bardem films that were screened in East Germany only Calle Mayor (Main Street, 1956) was shown in the West. ${ }^{8}$

Set in a small hill town - the film was in fact shot in Spanish locations-Solange du lebst relates the story of Theresa, a young Spanish woman, and the downed German pilot Michael. Played by Marianne Koch, who had previous acting credits as the young romantic counterpart to conflicted military figures in Helmut Käutner's Des Teufels General (The Devil's General, 1954) and the aforementioned biopic by Weidenmann, the pious Theresa discovers the wounded German pilot while fleeing the Republican forces that have taken over her village. Risking her life by secretly bringing him food and medicine in a cave in the hills, Theresa cares for Michael, who is respected as one who has put his life in danger in coming to the aid of the Spanish people. During the period of hiding and what is depicted as the bloody rule of the Communists in the town, Theresa 
and Michael fall predictably in love. Yet the pull of national belonging eventually comes in the way of their union. When the town is retaken by the Nationalists, sending the inhabitants into a frenzy of celebration, Theresa recognizes that she must return to her fiancé, a Spanish officer, who has been waiting for her while she has been entrapped in the enemy-held town. Michael's heart also propels him in a different direction. Feeling the call of the German Heimat or homeland in the final scene following the reunion of Theresa and her fiancé, he announces his intention to return to his native country. "Set a course for home," he exclaims in a trance-like tone as his face-transfixed in a gaze full of longing-dissolves into the image of the remaining German combat planes flying into the distance.

By the time of the production of Solange du lebst, Harald Reinl, who began his film career in front of the camera as a skier in mountain films directed by Arnold Fanck and later served as assistant to Leni Riefenstahl in the production of Tiefland (Lowlands, 1944), was well on the way to establishing himself as one of the early post-war era's most successful filmmakers. The initiator of two of the most successful post-war serials, based on the detective stories of Edgar Wallace and Karl May's westerns, Reinl specialized in genre films of all kinds, but particularly in the Heimatfilm, including his first colour film, Die Fischerin vom Bodensee (The Fisher-girl from Bodensee, 1956), and Die Zwillinge vom Zillertal (The Twins from Zillertal, 1957). With the exception of Die Grünen Teufel von Monte Cassino (The Green Devils of Monte Cassino, 1957) and U 47-Kapitänleutnant Prien (U-47-Lt. Commander Prien, 1958)—made at the insistence of his main distributor, Constantin-FilmverleihSolange du lebst was one of Reinl's few war film efforts. Created as a vehicle for Marianne Koch and featuring Katrin Dor, who would become one of the most popular female stars of the Federal Republic, the film was seen as too militaristic by the FSK (Freiwillige Selbstkontrolle), the West German film industry's self-regulating body, which demanded cuts and re-editing. The film was distributed in the United States by RKO until the studio went bankrupt. ' The version that reached West German audiences projects at best an ambiguous, contradictory, and 
generalized image of war-not to mention a tacit endorsement of the role Nazi Germany played in supporting the cause of Franco.

Solange du lebst opens with a panorama of the barren Andalusia countryside. As the camera pans across the arid hills, a voice-over situates the narrative as the "story of two people who met in this country at a time when brother fought against brother and the men of other countries also fought for the symbols of both fronts." In casting the war as a quasi-fraternal conflict over unspecified symbols — as opposed to political ideals or ideologies — the film drains its historical referent of specificity, obscuring the role of Germany's support of Franco by assisting in the movement of fascist troops as well as through the missions of the infamous Legion Condor, a squadron sent to Spain by Hitler in order to assist the fascist effort and to test German military technology in preparation for the Nazis' European war effort. ${ }^{10}$ While German air support for Franco's army is not explicitly connected to the Legion Condor in Solange du lebst, it was certainly present in the minds of German audiences in the early post-war period. Into the late 1960s West Germany's relationship to Franco's Spain was relatively friendly, with economic and other agreements. In the GDR, officials pointed not only to such ties, but also to the fact that former Legion Condor members responsible for the devastation on 26 April 1937 of the Basque town of Guernica, made famous by Picasso, had assumed important positions in rebuilding the West German air force. ${ }^{11}$

While Solange du lebst projects the incoherent ideological mixture typical of treatments of war in 1950s West German cinema, as exemplified by the dissembling introductory narration and appeals to sacrifice and valour, the film rather consistently comes down on the side of Franco's fascist government. The town's Polish commander during the occupation, Malek, is ruthless in his efforts to hold the town; the communist mayor is his morally torn puppet. Whereas Franco's supporters are linked to tradition, order, and church - the cross that Theresa wears around her neck features prominently in several scenes and Michael's place of hiding carries similar Christian connotations 
- the Republicans are a motley crew of multi-nationals who assault local women and take no prisoners. On the other hand, the mayor is shown as a conflicted figure, struggling to reconcile his ideals and sense of duty to the working class with the injustices being perpetrated under his regime.

The GDR's single feature-film studio, DEFA (Deutsche Film-Aktiengesellschaft), was of course confronted with a fundamentally different situation with respect to Germany's military past and developed different strategies for negotiating culpability, frequently evacuating Nazism to its capitalist neighbour to the west and situating the GDR as the heir to progressive trends in German history. Lacking traditional and historically rooted narratives of nation, the East German state looked to alternative sources of ideological grounding in the course of German history. The Spanish Civil War, which pitted a Franco-led Spanish military against a legitimately elected Popular Front government comprised of a loose affiliation among Republicans, socialists and communists (and supported electorally by anarchosyndicalists as well), played a central role in foundational antifascist narratives on the ideological genesis of East Germany. Whereas Franco was joined during the conflict by German and Italian fascists, left-wing leaders in Madrid sought the help of the Soviet Union, leading to the mobilization of supporters from all over Europe. The illegal German Communist Party actively recruited for the struggle and issued a manifesto on 7 August 1936 directed at the diaspora of German émigrés. German communists living in exile in France, Switzerland, and Spain responded in the thousands. Nearly 40,000 foreign volunteer recruits fought in the International Brigades, with over half of these transported to Spain by the Comintern. Around 3,000 Germans were among them, representing about one-sixth of all foreign combatants on the Loyalist/Republican side. Half of the Germans died in Spain and many of the survivors ended up in concentration camps in Germany.

By the time Fünf Patronenhülsen premiered on 3 November 1960 at East Berlin's "Colosseum," the Spanish Civil War and the role of German "Spanienkämpfer" were firmly installed as a heroic narrative at the core of official discourses on the history 
and identity of the GDR as the heir to an anti-fascist, democratic and socialist state. German veterans of the struggle against Franco had risen to high levels in the GDR government and communist-friendly interpretations of the war were popularized by autobiographies and novels. Memorials, street names, stamps and anniversary celebrations also served to commemorate the sacrifice of German communists to the anti-fascist effort. ${ }^{12}$

As Peter Monteath has explained, the historiographic accounts of the Spanish Civil War that emerged in East Germany remained relatively static, focusing on the role of German communists and downplaying the significant political rifts in the leftist forces that had joined to fight the Nationalists. ${ }^{13}$ The Twentieth Party Congress of the Communist Party of the Soviet Union in February 1956, however, which saw the rehabilitation of Spanish Civil War veterans who had been victims of Stalin's purges, did precipitate a shift. Whereas officially sanctioned treatments of the Spanish Civil War had up to this point highlighted the humanitarian contribution of the Soviet Union, after Khrushchev's critique of Stalin the Soviet military contribution was given more importance. Peter Monteath (1990, pp. 260-61) has conjectured that the era of decolonization may have played a role in this shift of emphasis. From this perspective, acknowledging the Soviet military intervention during the Spanish Civil War harmonized with the post-war politics of the Eastern Bloc with respect to Third World independence movements. Finally, the production of Fünf Patronenhülsen also coincided with the creation in the GDR of a National Defence Council (Nationaler Verteidigungsrat) which in 1962 transformed the country's previously voluntary military into a compulsory one.

Previous to Beyer's war drama, DEFA had mounted two films in which the conflict features: Karl Paryla's Mich dürstet (Plagued by Thirst, 1956) and Martin Hellberg's Wo du hingehst (Wherever You Go, 1957). ${ }^{14}$ Fünf Patronenhülsen was director Frank Beyer's first true success at DEFA. Not yet 30 and working with the still unknown Manfred Krug and Armin MuellerStahl, the director would go on to become one of the studio's most talented filmmakers. Trained in Prague and influenced by 
developments in Polish and Czech cinema, Beyer showed a particular aptitude for reworking genre frameworks for the DEFA context, most infamously, perhaps, in his banned Spur der Steine (Trace of the Stones, 1966), which gestured to the western in its critique of bureaucracy and incompetent planners at a mammoth construction site in the GDR.

The production of Fünf Patronenhülsen also coincided with a significant shift in DEFA's production strategy at the close of the 1950s. Whereas much of the studio's entertainment film production through the decade had relied on film professionals residing in West Berlin, by the end of the decade only very few commuters remained. Having broken ties with directors such as Hans Deppe, Hans Heinrich and Helmut Weiss, cinematographers such as Fritz Lehmann and actors such as Werner Peters, Fritz Wagner and Paul Esser, DEFA geared up to increase its own genre film production at a time when the film industry was coming under increasing pressure from television and experiencing a corresponding drop in movie attendance. In fact, GDR cinema of the early 1960s displays a diverse array of genres: musicals, adventure films and other popular forms that would seldom be matched in DEFA's history.

Images of war, of course, were not absent from GDR movie houses. Russian imports and films of resistance from other Eastern European countries brought the war back to East German movie-goers from the perspective of the Eastern victors. But Hollywood-style combat films set during the Second World War, of the kind flooding West German cinemas beginning in the mid-1950s, were not on the bills of GDR cinemas. In this situation the Spanish Civil War offered a surrogate war scenario that allowed for the projection of German heroism and sacrifice in a way that harmonized with overarching ideals of anti-fascism. Set during the withdrawal of Republican forces across the Ebro River, Fünf Patronenhülsen relates the story of an International Brigade that has been charged with defending a military position until the rest of the troops have safely retreated. During this time, the brigade, composed of the German Commissar Wittig, the Bulgarian Dimitri, the Russian radioman Wasja, the young Berliner Willi, the Polish gunner Oleg and the 
Frenchman Pierre, will be cut off from the rest of the Republican militia. The drama unfolds not only as a battle against Franco's forces, but as a struggle against the brutal heat of the Sierra. When Commissar Wittig is fatally wounded early in the narrative, he sends the remaining brigade members off with the exhortation to stay together if they hope to survive. In the end the remaining members of the brigade are reunited with their battalion on the other side of the Ebro. In terms of narrative configuration and iconography, Fünf Patronenhülsen reveals many of the features of the combat film as laid out by Jeanine Basinger (2003) in her exhaustive taxonomy of the Hollywood genre, which is adopted here less as a prescriptive blueprint than as a highly affective audiovisual space for negotiating themes of the individual, solidarity, integration, and sacrifice for a greater good.

Fünf Patronenhiulsen opens with a gesture to authenticity typical of the genre: with the title credits projected onto the image of jagged rocks against a blinding sky, the unmistakable and authoritative voice of Ernst Busch, himself a veteran of the Spanish Civil War, intones the song of the "Jamara Front." As the music continues, the individual brigadiers are introduced one by one, beginning with Commissar Wittig. In addition to the establishing roll call and appeal to authenticity of the credit sequence, other typical features of the combat film referenced by Beyer's film include: the importance of a specific military objective; a series of smaller struggles with the enemy and the surroundings; a conflict within the group that is resolved by the need to confront outside forces; military iconography (not just the hardware, but paraphernalia such as cigarettes-Russian Papyrossi for the antifascist brigadiers, capitalist Lucky Strikes for Franco's soldiers); physical hardship (here the lack of water in particular); the death of members of the unit; and a climactic battle accompanied by learning or growth.

In engaging the conventions of the World War II combat film-reconfigured in the proxy struggle of the fight against Franco-the film performs a comprehensive ideological recoding that is apparent on a number of levels and particularly conspicuous in the dynamics of the brigade itself. While in the 
Hollywood variant the identities of the combat unit can be marked by ethnicity, race, class, and region (Midwesterners prove to be reliable, Southerners are naïve but good marksmen, New Englanders have schooling, New Yorkers are sophisticates with attitude), by comparison differences among the brigadiers in Fünf Patronenhülsen are relatively muted. The levelling of national distinctions, for instance, is conveyed in an early scene in which the members of the brigade turn in their identification papers to their commander before engaging in their mission. Cold War geopolitics do affect characterization and motivation in a few instances, however. It is perhaps symptomatic that it is the Frenchman, the only brigade member from outside the communist bloc, who wavers during the brigade's trials while separated from the battalion. Breaking away from the others to search for water, Pierre pays with his life for deserting his comrades, thus suffering a fate that is generally reserved in the Hollywood combat film for racial and ethnic minorities. Similarly, a particularly harrowing death—an acknowledgement of the enormous sacrifice of the Russian people in defeating Nazism - is reserved for Wasja, who, exhausted after days in the heat without food and water, is captured by the fascists, bound, and dragged behind a horse. The brigade also includes the obligatory observer figure in Willi, a young Berliner who secretly writes poetry and is thus symbolically aligned with German Geist. In a gesture to the role of benevolent Russian culture officers in the legend of DEFA's creation, Willi's poetic aspirations are appreciated in a brief scene by the Russian commander of the battalion, who leaves nothing undone in trying to locate the promising future poet and his other missing men.

In the film, solidarity among the members of the brigade is at once necessary for survival and a moral ideal that ultimately trumps the military objective, lending the film a highly stylized, parable-like character underscored by the expressionistic framing and harsh lighting and the structuring effect of the visual and narrative repetition of the thirst motif. After exhorting his men to stay together, Wittig fabricates an encounter with a fascist combatant in which he claims to have come into possession of the plans for the next attack of Franco's militia. The five 
remaining brigadiers each believes himself to be in possession of a section of this plan, sealed in one of the title's five spent cartridges. Only by staying together will the plan arrive intact at battalion headquarters. At the end of the film it is revealed that instead of crucial military information, they have been carrying all along the transcription of Wittig's exhortation: "Stay together and you will survive." There is a certain logic to this displacement of the importance of the military goal in favour of an ideal - international solidarity among communists. In light of the historical failure of the Republican forces-Franco ruled in Spain into the 1970s - the film invests in an ideal that would resonate in the present of 1960 . More significant than any temporary victory in a historically lost battle the film could project is a message about the importance of unity among the socialist nations and the necessity of sacrifice for a greater cause.

Finding an appropriate visual form for the screenplay by Walter Gorrisch, who had first-hand experience of the war in Spain, was a priority for Beyer, who worked out a comprehensive "optisches Drehbuch" detailing the visual construction of every shot. Intent on projecting an affective Sierra landscapeshooting on location in Franco's Spain was clearly impossibleBeyer expended his limited budget (and coveted foreign currency) for exteriors in Bulgaria and was forced to abandon the idea of engaging authentically foreign (and more expensive) actors for the International Brigade. The director also risked a confrontation with DEFA in his insistence that a $28 \mathrm{~mm}$ lens be constructed in the studio shop that would allow him additional depth of field in the many close-ups that he planned to shoot. ${ }^{15}$

In an essay on the film's production, Beyer noted that many dialogues were eliminated during pre-production and replaced with visual strategies for conveying the same meaning. During production, according to the director, dialogues were cut by another quarter. ${ }^{16}$ The emphasis on visuals over dialogue is enhanced by instances of subjective camerawork and montage which once again suggest a commitment to what would seem, for DEFA, to be an uncharacteristic appeal to a cinema of affect. The film's many repetitions of the motif of dehydration and hunger also work in this capacity, as does the film's ending in 
which the remaining brigade members are re-hydrated in the water of the Ebro.

The best example of this is perhaps Wasja's water hallucination. Again, it is only one of a number of sequences that reinforce the motif of bodily dehydration introduced in the credit sequence in which the Pole Oleg sacrifices the last swallows of water from his canteen to the cooling chamber of his machine gun. These repeated images of the struggle against heat and starvation - which are contrasted with the decadence of fascist officers drinking wine-contribute to the projection of a cinema of affect that works to instil the image of sacrifice towards a greater goal. Staggering in the heat in search of his comrades, Wasja's fantasy is stimulated by a glance into a mirror-like shard, which he has been using to signal for help. In a point-of-view shot the reflective surface dissolves into a geometrical array of glasses of effervescent water. In this subjective montage, Wasja hallucinates a motherly Russian figure, who urges him to go to town for water. Pressing forward against a crowd of pedestrians, the glasses of water begin to rotate in his vision; following an extreme close-up of his severely chapped lips in a superimposition with the water glasses, he screams: "Water!" The crash of the mirror breaking also disrupts the hallucination. Having shifted from this modernist mode of subjectivity, the camera now follows Wasja in a long shot as he enters a small village. The townspeople, fearful of reprisals from the fascists if they appear to be abetting possible Republican fighters, watch him with a mixture of fear, sympathy and the recognition that he has put himself into danger by exposing himself in the open. And, sure enough, betrayed by a Catholic priest, who rings the Church bell to alert the fascists, Wasja is captured, bound, and dragged through the town behind a horse.

The image of German suffering is particularly developed in the figure of Commissar Wittig. Early in the film, Wittig is wounded by enemy fire and laid out to expire in a funereal cave, described in the film as a "shepherd's cave," with its connotations of peasant simplicity and Christian imagery. It is in this almost sacred space that Wittig gives his final order and bequeaths his boots to the Spaniard José. In the remainder of 
the film, Wittig's body remains absent, but the idea of struggle and solidarity continue. When Wasja later discovers the corpse in horror, Wittig remains out of sight of the spectator, who witnesses only the anguished expression on Wasja's face in a closeup. Wittig, the embodiment of Communist sacrifice, haunts the rest of the film as a symbol of Communist solidarity and perseverance. Only after the pieces of his message are reassembled at headquarters in the presence of the Russian commander on the other side of the Ebro does he appear in close-up, a spectre of the dead re-visualized. Mirroring the introduction of the brigade at the onset of the film, the "Jamara Front" fades in and the brigadiers again pass revue in a series of close-ups. The final image is Wittig's profile on his deathbed.

Solange du lebst and Fünf Patronenhülsen would seem to engender diametrically opposed ideological standpoints. In contrast to Fünf Patronenhülsen's anti-fascism and communist internationalism, Solange du lebst can be read as an apology for Nazi military support of Franco with strong anti-communist overtones. As such it shares the politics of West German war films set during the Second World War. But despite such diverging politics, both films seek to find workable representations of German sacrifice and valour for their respective contexts, drawing on related figurations of suffering. In light of the historical failure of the international brigades to defeat Franco, Beyer's film recoups the sacrifice of German combatants for a message that would resonate in the geo-political present of 1960 . Proceeding from a decidedly less noble cause, Solange du lebst projects images of German suffering which harmonized with discourses on the remilitarization of West Germany and the effort to construct an honourable tradition of military service which encompassed the Nazi period without explicitly embracing the content of its politics. Thus, despite their radically different motivations-not to mention the far more interesting visual strategies of Beyer - the two productions reveal a shared if differently focused preoccupation with German suffering and sacrifice. 


\section{NOTES}

1. I wish to thank the Social Sciences and Humanities Research Council of Canada (SSHRC) and the Connaught Foundation for generous support of a larger project on interGerman film relations and popular cinema of which this article is a preliminary case study.

2. Overviews which also point to inter-German contexts during the period are Thomas Heimann, DEFA, Künstler und SED-Kulturpolitik (1994) and Ralf Schenk, "Mitten im Kalten Krieg" (1994). See also Katie Trumpener's forthcoming The Divided Screen: The Cinemas of Postwar Germany. For a case study, see my "Finding Navigable Waters: Inter-German Film Relations and Modernisation in Two DEFA Barge Films of the 1950s" (Soldovieri 2006).

3. The notion of "contrastive dialogue" has been suggested by Hening Wrage and Thomas Beutelschmidt in their DFG-funded project "Programmgeschichte des DDR-Fernsehens Komparativ."

4. See Moeller 2001.

5. The following sketch of the West German context draws on Anton Kaes, From Hitler to Heimat: The Return of History as Film (1989, pp. 16-17) and Robert Moeller, "Victims on the Silver Screen: West German War Movies and the 'Unmastered Past'" (2006, p. 9). See also von Bedow 1975 (pp. 316-26) and Wegmann 1980.

6. Moeller (2006, p. 9) offers compelling readings of a number of West German war films in the context of West German remilitarization and discourses of victimization.

7. See Alegre 1996. The film was released in Germany as Gefangene der Hölle on 22 November 1957.

8. GDR releases of Bardem's films also included: La venganza (Vengeance, 1958), released as Die Rache; Nunca pasa nada (A Woman Passed By, 1963), released as Eine Frau ging vorbei; and El puente (Foul Play, 1977), released as Ein langes Wochenende. Preduprazhdenieto was released in the GDR as Die Mahnung and Calle Mayor as Die Hauptstrasse.

9. I first encountered the film in a poor-quality, dubbed video release that appears to correspond to the English-language RKO version. I later viewed the $35 \mathrm{~mm}$ copy at the Deutsches Institut für Filmkunde (DIF) in Wiesbaden. I would like to thank the DIF staff for arranging the flatbed screening.

10. The Legion Condor had been the subject of two Nazi propaganda films directed by Karl Ritter in 1939, the war documentary Im Kampf gegen den Weltfeind: Deutsche Freiwillige in Spanien (Struggle against the World Enemy: German Volunteers in Spain) and Legion Condor.

11. See Monteath 1990 (p. 260).

12. See McClellan 2004 for a fine account of the contested memory of the Spanienkämpfer in the GDR. The discussion brushes the cultural sphere but does not address film. Peter Monteath's The Spanish Civil War in Literature, Film, and Art: An International Bibliography of Secondary Literature (1994) offers an extensive if not exhaustive international overview.

13. Peter Monteath (1990) offers a valuable overview of interpretations of the Spanish Civil War in the two Germanys in Monteath (1994).

14. There is also a Spanish Civil War thread in Konrad Wolf's Leute mit Flüglen (People with Wings, 1960). The film points to the actions of the Nazi Legion Condor in Spain and the involvement of German industry in supporting Franco.

15. See the account of the dispute between the resolute young director and the film's producer in Geiss 1997 (pp. 74-75).

16. See Beyer 1961 (p. 3). 


\section{BIBLIOGRAPHICAL REFERENCES}

Alegre 1996: Sergio Alegre, "The Blue Division in Russia, 1941-1944: The Filmic Recycling of Fascism as Anticommunism in Francos' Spain," The Historical Journal of Film, Radio and Television, Vol. 16, no. 3, 1996, pp. 349-364.

Basinger 2003: Jeanine Basinger, The World War II Combat Film: Anatomy of a Genre, Middleton, Wesleyan University Press, 2003.

Beyer 1961: Frank Beyer, "Fünf Patronenhülsen. Aus dem Werkstatt des Regisseurs," Filmwissenschaftliche Mitteilungen, supplement to Deutsche Filmkunst, 1961.

Geiss 1997: Axel Geiss, Repression und Freiheit, Potsdam, Brandenburgische Landeszentrale für politische Bildung, 1997.

Grass 2007: Günter Grass, Peeling the Onion, Orlando, Harcourt, 2007.

Heimann 1994: Thomas Heimann, DEFA, Künstler und SED-Kulturpolitik, Berlin, Vistas, 1994.

Kaes 1989: Anton Kaes, From Hitler to Heimat: The Return of History as Film, Cambridge, Harvard University Press, 1989.

McClellan 2004: Josie McClellan, Antifascism and Memory in East Germany: Remembering the International Brigades 1945-1989, Oxford, Clarendon, 2004.

Moeller 2001: Robert G. Moeller, War Stories: The Search for a Usable Past in the Federal Republic of Germany, Berkeley, University of California Press, 2001.

Moeller 2006: Robert G. Moeller, "Victims on the Silver Screen: West German War Movies and the "Unmastered Past," History Lessons: German Films about the Third Reich and the Holocaust, Austin, University of Texas Press, 2006.

Monteath 1990: Peter Monteath, "German Historiography and the Spanish Civil War: A Critical Survey," European History Quarterly, Vol. 20, no. 2, 1990, pp. 255-83.

Monteath 1994: Peter Monteath, The Spanish Civil War in Literature, Film, and Art: An International Bibliography of Secondary Literature, Westport, Greenwood Press, 1994.

Schenk 1994: Ralf Schenk, "Mitten im Kalten Krieg," in Ralf Schenk (ed.), Das zweite Leben der Filmstadt Babelsberg, Berlin, Henschel, 1994, pp. 51-157.

Soldovieri 2006: Stefan Soldovieri, "Finding Navigable Waters: Inter-German Film Relations and Modernisation in Two DEFA Barge Films of the 1950s," Film History, Vol. 18, no. 1, 2006, pp. 59-72.

von Bedow 1975: Wilfried von Bedow, "Filmpropaganda für die Wehrbereitschaft. Kriegsfilme in der Bundesrepublik," in Wilfried von Bedow and Rolf Zurek (eds.), Film und Gesellschaft in Deutschland. Dokumente und Materialien, Hamburg, Hoffmann und Campe, 1975, pp. 316-26.

Wegmann 1980: Wolfgang Wegmann, Der westdeutsche Kriegsfilm der fünfziger Jahre, Cologne, DFD, 1980.

\section{RÉSUMÉ}

\section{La souffrance des Allemands en Espagne: points de vue de la guerre froide sur la guerre civile espagnole dans Fünf Patronenhülsen (1960) et Solange du lebst (1955)}

\section{Stefan Soldovieri}

Depuis 1989, les liens entre les industries cinématographiques de ce qui avait été jusque-là deux Allemagnes géopolitiquement 
divisées, attirent de plus en plus l'attention. Le présent article propose d'étudier comment deux films d'après-guerre - l'un produit en Allemagne de l'Est, l'autre en Allemagne de l'Ouest - représentent de différente façon la souffrance et le sacrifice allemands. L'auteur défend l'idée que malgré leurs horizons politiques opposés, les deux films participent d'un discours de la souffrance qui transcende la dualité de l'Allemagne et qui, au-delà de ses transformations historiques, demeure constant tout au long de la guerre froide. 